\title{
THE STUDY OF PARTICLE SIZE DISTRIBUTION OF MICRONIZED OAT BRAN LAYER
}

\author{
Dariusz Dziki $^{\mathrm{a}, \mathrm{d}^{*}}$, Wojciech Tarasiuk ${ }^{\mathrm{b}, \mathrm{d}}$, Grzegorz Łysiak ${ }^{\mathrm{c}}$, Paweł Jochymek ${ }^{\mathrm{d}}$ \\ a Department of Thermal Technology and Food Process Engineering, University of Life Sciences \\ in Lublin, Poland, e-mail: dariusz.dziki@up.lublin.pl, ORCID 0000-0003-4879-4404 \\ b Department of Mechanics and Applied Computer Science, Białystok University of Technology, \\ Poland, e-mail: w.tarasiuk@pb.edu.pl, ORCID 0000-0001-9680-1328 \\ ${ }^{\mathrm{c}}$ Department of Food Engineering and Machines, University of Life Sciences in Lublin, Poland, \\ e-mail: grzegorz.lysiak@up.lublin.pl, ORCID 0000-0002-4950-7481 \\ d Silcar Sp. z o.o., Katowice, Poland, e-mail: biuro@ silcar.pl \\ *Corresponding author: e-mail: dariusz.dziki@up.lublin.pl
}

\begin{tabular}{|c|c|}
\hline ARTICLE INFO & ABSTRACT \\
\hline $\begin{array}{l}\text { Article history: } \\
\text { Received: April } 2020 \\
\text { Received in the revised form: } \\
\text { May } 2020 \\
\text { Accepted: May } 2020 \\
\end{array}$ & $\begin{array}{l}\text { The aim of this work was to study the particle size distribution of } \\
\text { micronized oat bran. An impact classified mill was used to pulveriz- } \\
\text { ing. Before the pulverizing raw material was sterilized using overheat- } \\
\text { ed steam at } 150^{\circ} \mathrm{C} \text { during } 3.5 \text { min. The moisture of bran after steriliza- } \\
\text { tion decreased from } 7.2 \text { to about } 3.9 \% \text {. Five speeds of the rotor disc }\end{array}$ \\
\hline $\begin{array}{l}\text { Key words: } \\
\text { oat bran, } \\
\text { micronization, } \\
\text { ultra-fine grinding, } \\
\text { particle size distribution, } \\
\text { sensory evaluation }\end{array}$ & $\begin{array}{l}\text { were used: } 2600,2970,3340 \text {, and } 3710 \mathrm{rpm} \text {. For each speed of the } \\
\text { rotor disc the following speeds of classifier wheel were applied: } 480 \text {, } \\
965,1450,1930,2410 \text { and } 2890 \mathrm{rpm} \text {. The particle size distribution of } \\
\text { oat bran layer was measured by laser light scattering. Moreover, the } \\
\text { sense of touch of coarse particles of micronized oat bran on a tongue } \\
\text { was assessed according to five point scale. The largest fragmentation } \\
\text { of the oat bran was obtained at a disc speed of } 3710 \mathrm{rpm} \text { and at } \\
\text { a classifier rotation speed of } 1930 \mathrm{rpm} \text {, whereas the most coarse } \\
\text { particles were obtained when these parameters were } 3340 \mathrm{rpm} \text { and } \\
480 \mathrm{rpm} \text {, respectively. On the other hand, the highest uniformity in } \\
\text { size of particles in size was observed when the lowest speed of disc } \\
\text { and classifier were used. Moreover, for the most samples the pulver- } \\
\text { ized particles of oat bran were almost not discernible on tongue. }\end{array}$ \\
\hline
\end{tabular}

\section{Introduction}

Oat (Avena sativa) has many potential health benefits. Oat is especially source of nondigestible fibre( $\beta$-glucan) with unique properties. $\beta$-glucan reduces the risk of type 2 diabetes and cardiovascular disease (Vizuete and Anta, 2016). Moreover, this compound reduces the blood cholesterol lever (Liatis et al., 2009) and helpcontrol level of glucose and insulin response (Vizuete and Anta, 2016). $\beta$-Glucan is able to attenuate glycemic response, increase satiety after meal, and stimulate healthy gut microflora (Dotsenko et al., 2019). However, a most of people do not consume the suggested daily fibre intake and especially $\beta$-glucan (Salmas et al., 2017). In oat $\beta$-glucan is mainly located in bran and aleurone layers 
(Demirbas,2005). It is relatively inexpensive oat flour milling by-productand can be added to foods on the assumption that this willcontribute to health benefits (Bensalah et al, 2019,Xue et al., 2020).

Cereal flour particle size has a strong influence on flour properties and decides about properties of final products. Recently, the application of micronization in food products has gained a lot of attention (Frohlich et al., 2019,Protonotariou et al. 2020, Xue, et al., 2020).Micronization or superfine grinding is the process of reducing the particle size of material to nanosize (Chen et al., 2018).Ultrafine grinding technology changes properties of powdered rawmaterials and improves dispersion, chemical activity, biological activity and especially improves the nutritionalabsorption rate of food processed by the separatedraw materials (Zhu et al., 2014). In the case of rich fibre plant materials this process increases flour water absorption and solubility of dietary fibre (Hussain et al., 2018) but also releases flavor and improved mouth feel (Chen et al. 2018). Most importantly ultra-fine grinding enhances the antioxidant capacity of dietary fiber asa result of release many bioactive compounds bound to the food matrix (Bender et al., 2020, Liu et al., 2016, Zhu et al., 2014).

The aim of this work was to study the influence of working parameters of impact classified mill on the particle size distribution of micronized oat bran layer.

\section{Materials and Methods}

Material for the study was the oat bran layer received from ZMZM Kruszwica. The basic chemical composition of bran was determined (Romankiewicz et, al. 2017). Moreover the $\beta$-glucan content was assessed according to AOAC method (1995). Before the pulverizing material was sterilized using overheated steam at $150^{\circ} \mathrm{C}$ during $3.5 \mathrm{~min}$. The moisture content in raw material before and after sterilization was determined by drying the bran samples at $105^{\circ} \mathrm{C}$.Oat bran layer was pulverized using impact classified mill (capacity $\left.500 \mathrm{~kg} \cdot \mathrm{h}^{-1}\right)$. The mill cooperated with centrifugal fan with air flow $2 \mathrm{~m}^{3} \cdot \mathrm{s}^{-1}$. Raw material was transported by air into the milling chamber through the stub end with $60 \mathrm{~mm}$ diameter (Fig. 1). The bran layer was pulverized on the rotor disc ( $725 \mathrm{~mm}$ diameter) equipped with 12 hammers $(90 \times 25 \times 25 \mathrm{~mm})$. The following speeds of the rotor disc were used: 2600 , 2970, 3340, and $3710 \mathrm{rpm}$. Oat bran was pulverized by the hammers and was through on liner with corrugated surface. Pulverized material was transported through baffle assembly into classifier wheel, which allow or not to pass them outside the mill. Coarse particles were turn back into milling chamber. Classifier consistsof disc with $350 \mathrm{~mm}$ diameter and 36 vanes mounted at an angle $18^{\circ}$ (Fig. 2). For each speed of the rotor disc the following speeds of classifier wheel were used: 480, 965, 1450, 1930, 2410 and $2890 \mathrm{rpm}$.

The particle size distribution of oat bran layer was measured by laser light scattering using a laser particle size analyser (Malvern Mastersizer 3000 instrument, Malvern Instruments Ltd., Worcestershire, UK). In the laser diffraction measurement, a laser beam passes through a dispersed flour sample, and the variation in intensity of the laser light is measured. The angular scattering intensity is analyzed, and the size of the particles is calculated. A $5 \mathrm{~g}$ amount of pulverized sample was put into the inlet chamber, and particle size was measured automatically by laser diffraction using dry dispersion method. 


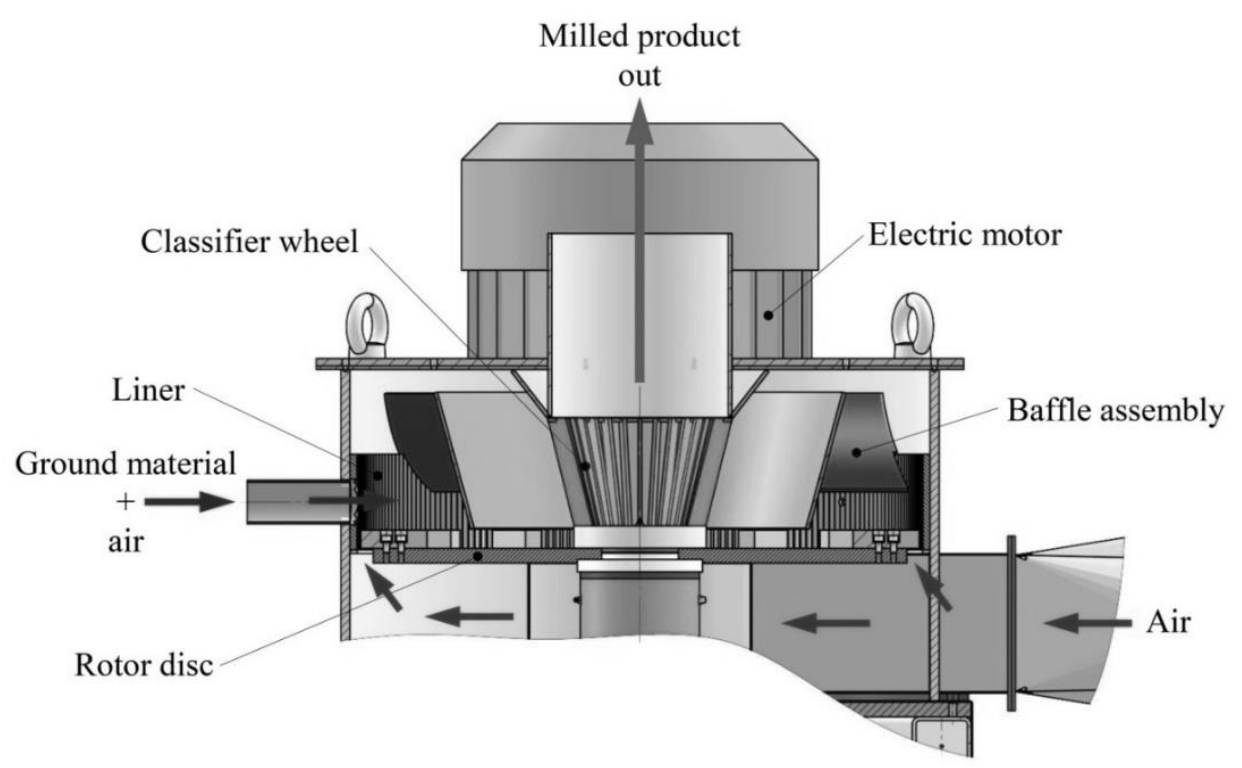

Figure 1. Process of micronization in impact classified mill
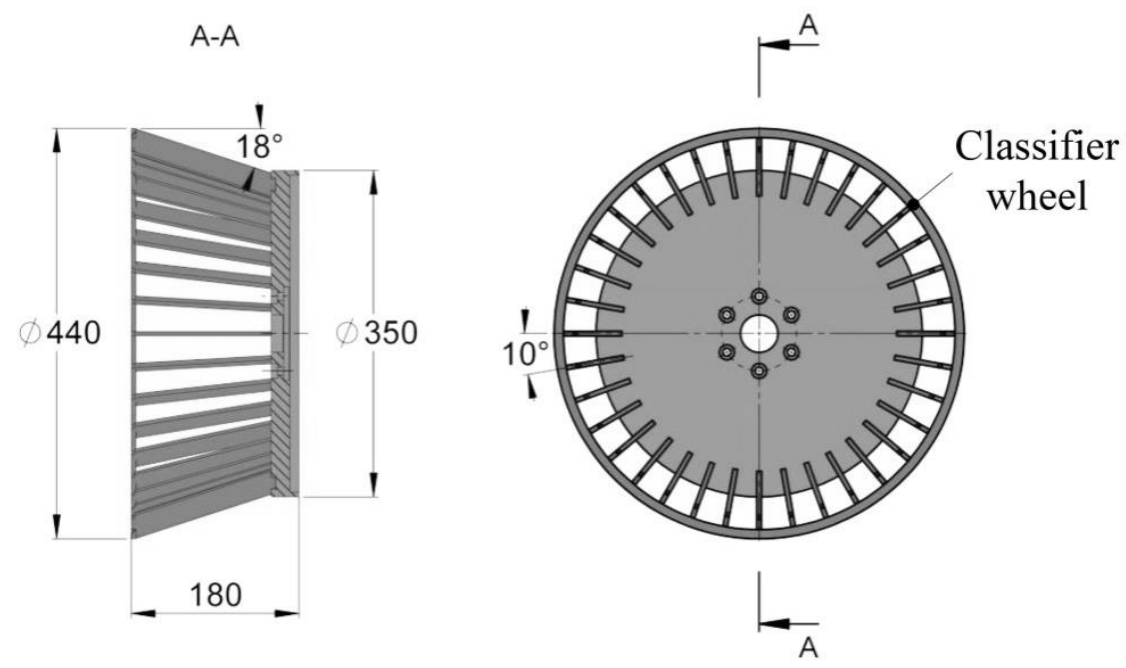

Figure 2. Diagram of classifier wheel 
Measurements were carried out in eight replicates for each sample. From each particle size distribution $d_{10}, d_{50}$ and $d_{90}$ were evaluated. These parameters represented the particlediameters that cumulative volume of particles was $10 \%, 50 \%$ and $90 \%$,respectively. The size dispersion index (Span) was also calculated accordingto the following equation (Liu et al., 2011):

$$
\text { Span }=\frac{d_{90}-d_{10}}{d_{50}}
$$

Moreover, the sense of touch of coarse particles on tongue in micronized oat bran was assessed according to five point scale: 1 - very discernible, 2 - discernible, 3 - slightly discernible, 4 - almost no discernible, 5 - no discernible. The evaluation was performed by five persons.Plain water was used to rinse mouth before and after each sample testing. The measurement was performed in triplicate for each sample.

The data were analyzed with Statistical program version 13.1. The mean values and standard deviations were calculated and the analysis of variance (two-way ANOVA), followed by the least significant difference test (Turkey test) were performed. The level of significance was $\alpha=0.05$.

\section{Results and Discussion}

The moisture content in the oat bran samples was $7.2 \% \pm 0.12$ before sterilization and between $3.69 \%$ and $4.21 \%$ after this process. The others components of oat bran were as follow: ash content $2.74 \% \pm 0.082$; protein content $16.3 \% \pm 0.814$, and $5.52 \% \pm 0.28$ of fat. The $\beta$-glucan content in oat bran was $8.0 \% \pm 0.31$.

The analysis of variance showed that both speed of disc and speed of classifier had significant influence on the parameters described the particle size distribution of pulverized oat bran. Also the interaction of these parameters was significant (Table 1). Taking into account the parameters $d_{10}, d_{50}$ and $d_{90}$, the highest values of $F$-test were alwaysobtained for revolution of classifier wheel. It means that this parameter had the highest influence on the grinding patter of pulverized oat bran. On the other hand the revolution of disc had the highest influence on span. The spanrepresents the width of particles volume distribution.

An example of particle size distribution of powdered oat bran is presented in Fig. 3 and the parameters describingthe particle size distribution of micronized oat bran layer for all samples were included in Table 2. Both speed of disc and revolution of classifier wheel had little influence on the amount of fine particles. As a result of this the parameter $d_{10}$ changed in the narrow range from $6.9 \mu \mathrm{m}$ (sample B21) to $9.1 \mu \mathrm{m}$ (sample B13). It means that for all micronized samples $10 \%$ of each sample has a size of $9.1 \mu \mathrm{m}$ or smaller. The lowest values of $d_{10}$ were found when the speed of disc was $3710 \mathrm{rpm}$ and the revolution of classifier equal 1450 and $1930 \mathrm{rpm}$. Higher variability was observed in the case of $\mathrm{d}_{50}$ (median). This parameter ranged from $19.9 \mu \mathrm{m}$ to $53.7 \mu \mathrm{m}$ for samples B22 and B13, respectively. Although the lowest values of $d_{50}$ were found in the most cases for the highest speed of disc we did not found the linear relation between speed of disc and the $d_{50}$. 
The study of particle size...

Table 1.

The analysis of variance of parameters characterizing the particle size distribution of pulverized oat bran layer

\begin{tabular}{|c|c|c|c|c|c|c|}
\hline Parameter & $\begin{array}{c}\text { Source } \\
\text { of variance }\end{array}$ & Sum of squares & $\begin{array}{c}\text { Degrees } \\
\text { of freedom }\end{array}$ & $\begin{array}{l}\text { Mean } \\
\text { square }\end{array}$ & $F$ - test & $p$-value \\
\hline \multirow{3}{*}{$d_{10}$} & $\mathrm{~V}_{\mathrm{w}}{ }^{*}$ & 7.27 & 3 & 2.42 & 403 & $<0.0001$ \\
\hline & $\mathrm{V}_{\mathrm{k}}$ & 36.21 & 5 & 7.24 & 1204 & $<0.0001$ \\
\hline & $\mathrm{V}_{\mathrm{w}} \cdot \mathrm{V}_{\mathrm{k}}$ & 23.75 & 15 & 1.58 & 263 & $<0.0001$ \\
\hline \multirow{3}{*}{$d_{50}$} & $\mathrm{~V}_{\mathrm{w}}$ & 1277.4 & 3 & 425.8 & 1144.9 & $<0.0001$ \\
\hline & $\mathrm{V}_{\mathrm{k}}$ & 6608.4 & 5 & 1321.7 & 3553.8 & $<0.0001$ \\
\hline & $\mathrm{V}_{\mathrm{w}} \cdot \mathrm{V}_{\mathrm{k}}$ & 4822.4 & 15 & 321.5 & 864.5 & $<0.0001$ \\
\hline \multirow{3}{*}{$d_{90}$} & $\mathrm{~V}_{\mathrm{w}}$ & 32450 & 3 & 10817 & 834.2 & $<0.0001$ \\
\hline & $\mathrm{V}_{\mathrm{k}}$ & 194349 & 5 & 38870 & 2997.8 & $<0.0001$ \\
\hline & $\mathrm{V}_{\mathrm{w}} \cdot \mathrm{V}_{\mathrm{k}}$ & 127246 & 15 & 8483 & 654.3 & $<0.0001$ \\
\hline \multirow{3}{*}{ Span } & $V_{w}$ & 27.850 & 3 & 9.283 & 1027.5 & $<0.0001$ \\
\hline & $\mathrm{V}_{\mathrm{k}}$ & 14.992 & 5 & 2.998 & 331.9 & $<0.0001$ \\
\hline & $\mathrm{V}_{\mathrm{w}} \cdot \mathrm{V}_{\mathrm{k}}$ & 36.804 & 15 & 2.454 & 271.6 & $<0.0001$ \\
\hline
\end{tabular}

$V_{w}$ - revolution of disc, $V_{k}$ - revolution of classifier wheel

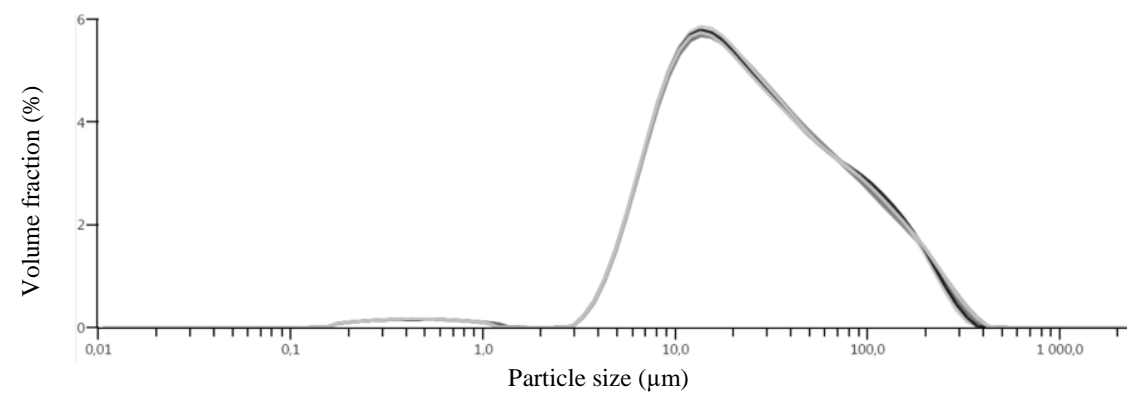

Figure 3. Example of particle size distribution curves (eight repetitions) of the micronized oat bran layer (sample M23) determined by laser diffraction

Taking into account the revolution of classifier the lowest value of this parameter were usually found for middle speed of classifier (965, 1450 and $1930 \mathrm{rpm}$ ). Relatively high content of fat in oat bran can cause a grinding and separation problem problems (Sibakov et al. 2011, Stevenson et al., 2008), particles are more plastic and can combine into agglomerates. This could be a reason why an increase in the speed of disc had relatively low influence on particle size distribution of micronized oat bran. Liu et al. (2015) studied the oat bran fragmentation by using the planetary rubbing mill. After six hours of grinding they 
obtained ground material with average particle size from 141 to $169 \mu \mathrm{m}$. Wu and Doehlert (2020) used a pin mill and defatted oat bran for powder production from oat bran. They obtained powder with average particle size between 86 and $184 \mu \mathrm{m}$. In our study we obtained much better degree of fineness of oat bran without defeating but with decreasing of moisture content up to about $3.9 \%$. Moisture of biological materials is a crucial parameter which decides about the grinding process. Materials with low moisture are more fragile and ground more easily in comparison to raw materials with higher moisture content (Dziki, 2008).

Table 2.

Parameters described the particle size distribution of micronized oat bran layer

\begin{tabular}{|c|c|c|c|c|c|c|c|}
\hline Sample & $\begin{array}{l}\text { Revolution } \\
\text { of disc } \\
(\mathrm{rpm})\end{array}$ & $\begin{array}{c}\text { Revolution } \\
\text { of classifier } \\
\text { wheel } \\
(\mathrm{rpm}) \\
\end{array}$ & $\begin{array}{c}\text { Moisture } \\
\text { content } \\
(\%)\end{array}$ & $\begin{array}{c}d_{10} \\
(\mu \mathrm{m})\end{array}$ & $\begin{array}{c}d_{50} \\
(\mu \mathrm{m})\end{array}$ & $\begin{array}{c}d_{90} \\
(\mu \mathrm{m})\end{array}$ & Span \\
\hline B1 & 2600 & 480 & 4.19 & $7.5 \pm 0.11^{\mathrm{gh} *}$ & $26.4 \pm 0.49^{i}$ & $107.4 \pm 3.74^{\mathrm{e}}$ & $3.8 \pm 0.07^{\mathrm{b}}$ \\
\hline B2 & 2600 & 965 & 4.21 & $7.2 \pm 0.07^{\mathrm{cd}}$ & $24.5 \pm 0.09^{\mathrm{gh}}$ & $95.1 \pm 0.77^{\mathrm{abc}}$ & $3.6 \pm 0.03^{\mathrm{a}}$ \\
\hline B3 & 2600 & 1450 & 4.07 & $7.4 \pm 0.10^{\text {ef }}$ & $24.7 \pm 0.24^{\mathrm{h}}$ & $93.2 \pm 1.16^{\mathrm{ab}}$ & $3.5 \pm 0.02^{\mathrm{a}}$ \\
\hline B4 & 2600 & 1930 & 4.11 & $7.8 \pm 0.06^{\mathrm{i}}$ & $28.8 \pm 0.18^{\mathrm{i}}$ & $122.4 \pm 1.41^{\mathrm{g}}$ & $4.0 \pm 0.03^{\mathrm{cd}}$ \\
\hline B5 & 2600 & 2410 & 4.23 & $8.1 \pm 0.08^{\mathrm{kl}}$ & $31.5 \pm 0.48^{\mathrm{k}}$ & $138.6 \pm 2.26^{\mathrm{h}}$ & $4.1 \pm 0.03^{\mathrm{de}}$ \\
\hline B6 & 2600 & 2890 & 4.31 & $8.1 \pm 0.041^{\mathrm{m}}$ & $33.6 \pm 0.60^{1}$ & $160.4 \pm 2.77^{\mathrm{i}}$ & $4.5 \pm 0.04^{\mathrm{hi}}$ \\
\hline B7 & 2970 & 480 & 4.19 & $8.2 \pm 0.06^{\mathrm{m}}$ & $35.2 \pm 0.89^{\mathrm{m}}$ & $189.0 \pm 5.40^{\mathrm{k}}$ & $5.1 \pm 0.10^{\mathrm{m}}$ \\
\hline B8 & 2970 & 965 & 3.85 & $7.4 \pm 0.08^{\mathrm{ef}}$ & $23.6 \pm 0.36^{\text {efg }}$ & $114.6 \pm 4.21^{\mathrm{f}}$ & $4.5 \pm 0.12^{\mathrm{hi}}$ \\
\hline B9 & 2970 & 1450 & 4.07 & $7.2 \pm 0.07^{\mathrm{cd}}$ & $22.5 \pm 0.18^{\mathrm{de}}$ & $106.5 \pm 2.98^{\mathrm{e}}$ & $4.4 \pm 0.10^{\mathrm{gh}}$ \\
\hline B10 & 2970 & 1930 & 4.05 & $7.1 \pm 0.06^{\mathrm{cd}}$ & $21.7 \pm 0.06^{\mathrm{cd}}$ & $97.9 \pm 1.95^{\mathrm{bc}}$ & $4.2 \pm 0.09^{\mathrm{ef}}$ \\
\hline B11 & 2970 & 2410 & 3.44 & $8.0 \pm 0.12^{\mathrm{jkl}}$ & $32.4 \pm 0.54^{\mathrm{k}}$ & $168.0 \pm 4.93^{\mathrm{i}}$ & $4.9 \pm 0.08^{1}$ \\
\hline B12 & 2970 & 2890 & 3.77 & $8.7 \pm 0.03^{\circ}$ & $45.4 \pm 0.89^{\circ}$ & $189.6 \pm 2.13^{\mathrm{k}}$ & $4.0 \pm 0.04^{\mathrm{cd}}$ \\
\hline B13 & 3340 & 480 & 3.81 & $9.1 \pm 0.07^{p}$ & $53.7 \pm 2.10^{\mathrm{p}}$ & $242.3 \pm 4.92^{\mathrm{m}}$ & $4.3 \pm 0.09^{\mathrm{fg}}$ \\
\hline B14 & 3340 & 965 & 3.85 & $7.9 \pm 0.09^{\mathrm{ijk}}$ & $26.9 \pm 0.84^{\mathrm{i}}$ & $163.4 \pm 6.78^{\mathrm{ij}}$ & $5.8 \pm 0.11^{\mathrm{n}}$ \\
\hline B15 & 3340 & 1450 & 4.01 & $7.1 \pm 0.07^{\mathrm{bc}}$ & $21.2 \pm 0.20^{\mathrm{bc}}$ & $105.4 \pm 4.67^{\mathrm{de}}$ & $4.6 \pm 0.19^{\mathrm{ijk}}$ \\
\hline B16 & 3340 & 1930 & 4.05 & $7.5 \pm 0.10^{\mathrm{fg}}$ & $24.4 \pm 0.38^{\text {fgh }}$ & $106.4 \pm 3.54^{\mathrm{e}}$ & $4.1 \pm 0.09^{\text {cde }}$ \\
\hline B17 & 3340 & 2410 & 3.94 & $7.9 \pm 0.08^{\mathrm{ij}}$ & $27.2 \pm 0.34^{\mathrm{i}}$ & $114.0 \pm 1.60^{\mathrm{f}}$ & $3.9 \pm 0.03^{\mathrm{bc}}$ \\
\hline B18 & 3340 & 2890 & 3.99 & $8.5 \pm 0.10^{\mathrm{n}}$ & $35.3 \pm 0.49^{\mathrm{m}}$ & $193.4 \pm 3.02^{\mathrm{k}}$ & $5.2 \pm 0.04^{\mathrm{m}}$ \\
\hline B19 & 3710 & 480 & 4.12 & $8.7 \pm 0.04^{\circ}$ & $37.8 \pm 0.43^{\mathrm{n}}$ & $225.1 \pm 3.00^{1}$ & $5.7 \pm 0.04^{\mathrm{n}}$ \\
\hline $\mathrm{B} 20$ & 3710 & 965 & 3.81 & $7.6 \pm 0.09^{h}$ & $23.3 \pm 0.24^{\mathrm{ef}}$ & $143.1 \pm 6.51^{\mathrm{h}}$ & $5.8 \pm 0.23^{\mathrm{n}}$ \\
\hline B21 & 3710 & 1450 & 3.46 & $6.9 \pm 0.06^{\mathrm{a}}$ & $20.5 \pm 0.16^{\mathrm{ab}}$ & $99.8 \pm 3.88^{\mathrm{cd}}$ & $4.5+ \pm 0.16^{\mathrm{h}}$ \\
\hline $\mathrm{B} 22$ & 3710 & 1930 & 3.08 & $7.0 \pm 0.06^{\mathrm{a}}$ & $19.9 \pm 0.05^{\mathrm{a}}$ & $91.1 \pm 1.96^{\mathrm{a}}$ & $4.2 \pm 0.09^{\mathrm{ef}}$ \\
\hline B23 & 3710 & 2410 & 3.68 & $7.2 \pm 0.03^{\mathrm{cd}}$ & $23.2 \pm 0.19^{\mathrm{e}}$ & $118.3 \pm 2.19^{f}$ & $4.8 \pm 0.07^{\mathrm{kl}}$ \\
\hline B24 & 3710 & 2890 & 3.69 & $7.3 \pm 0.09^{\mathrm{de}}$ & $22.8 \pm 0.06^{\mathrm{de}}$ & $114.8 \pm 0.89^{f}$ & $4.7 \pm 0.05^{\mathrm{jk}}$ \\
\hline
\end{tabular}

* The values designated by the different small letters $(a, b, c, d \ldots)$ are significantly different $(\alpha=0.05)$. 
The study of particle size...

Table 2 presents the span results. This parameter shows the width of the particle size distribution and gives an indication of how far the 10 percent and 90 percent points are apart, normalized with the midpoint. Interestingly the highest uniformity of particles in size was observed when the lowest speed of disc and classifier were used. This parameter changed from 3.5 (sample B3) to 5.8 (sample B14).

The result of sense of touch of coarse particles on tongue is presented on Fig. 4. Generally for the most ground samples of oat bran the coarse particles were almost not discernible. The lowest notes for the sense of touch were found when the speed of disc and classifier was $3340 \mathrm{rpm}$ and $480 \mathrm{rpm}$ (sample B13, Table 2, Fig. 4C), respectively and coarse particles were completely no discernible when the speed of disc was $3710 \mathrm{rpm}$ (Fig. 4A) and the speeds of classifier were 1450 and $1930 \mathrm{rpm}$ (B21 and B22 samples, Table 2). However, the significant differences were only found between the sample B13 and the samples B21 and B22. Beside this we found positive and significant correlation between $d_{90}$ and the sense of touch of coarse particles (Fig. 5).

A

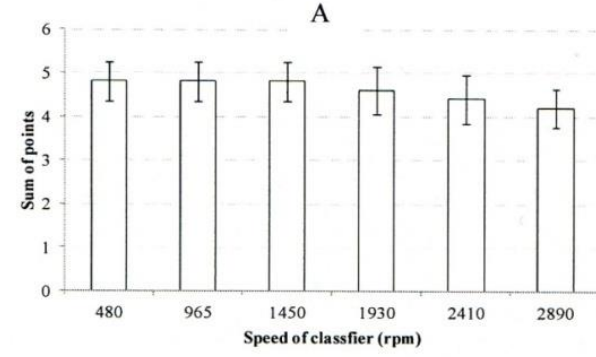

C

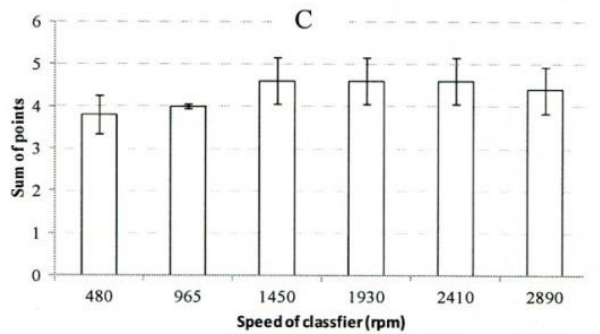

B

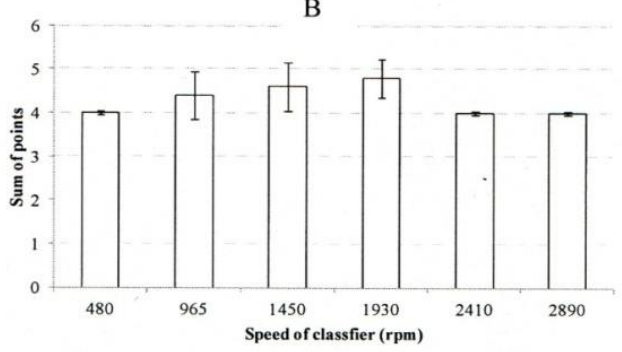

D

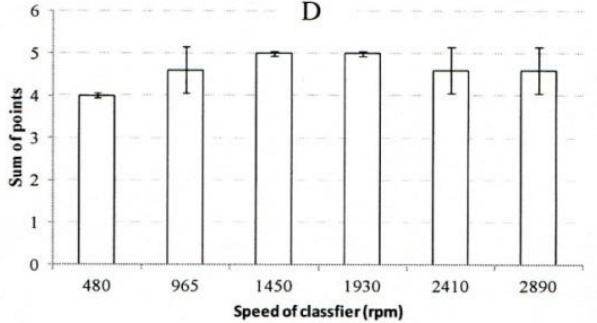

Figure 4. The result of sense of touch of coarse particles on tongue of micronized oat bran for different speeds of disc: $A-2600 \mathrm{rpm}, B-2070 \mathrm{rpm}, C-3340 \mathrm{rpm}, \mathrm{D}-3710 \mathrm{rpm}$ 
D. Dziki, W. Tarasiuk, G. Łysiak, P. Jochymek

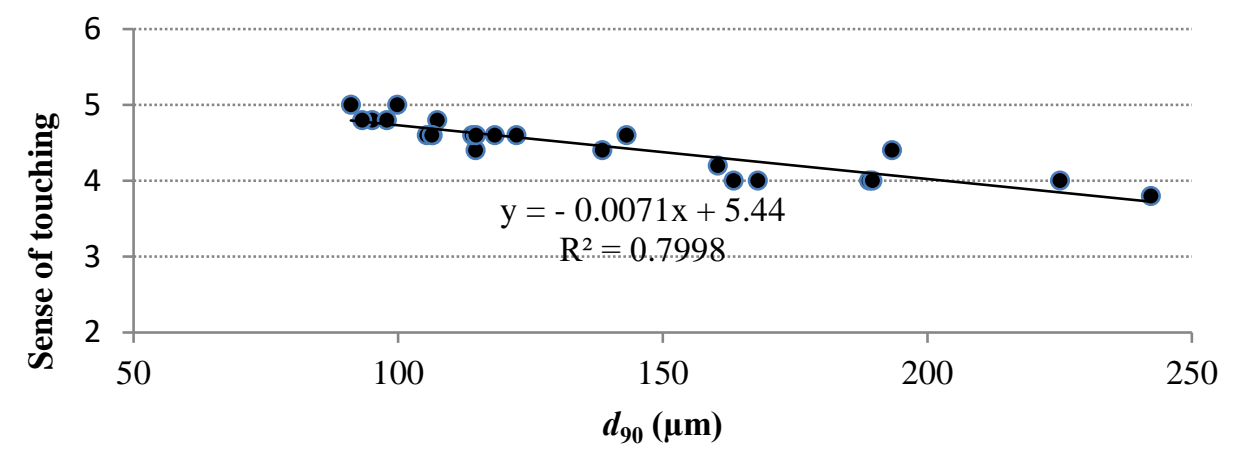

Figure 5. The relation between the $d_{90}$ parameter and the sense of touch of coarse particles on tongue

\section{Conclusions}

1. Although both the speed of disc and classifier significantly influenced on particle size distribution of oat bran, there was no linear relation between these parameters and the size of particles.

2. The largest fragmentation of the oat bran was obtained at a disc speed of $3710 \mathrm{rpm}$ and at a classifier rotation speed of $1930 \mathrm{rpm}$ whereas the most coarse particles were obtained when these parameters were $3340 \mathrm{rpm}$ and $480 \mathrm{rpm}$, respectively. On the other hand, the highest uniformity of particles in size was observed when the lowest speed of disc and classifier were used.

3. The evaluation sense of touch of coarse particles on tongue showed positive correlation with $d_{50}$ and $d_{90}$ parameters. Generally for the most samples the coarseparticles of pulverized oat bran were almost not discernible.

4. The result showed that proposed method of grinding is adequate to pulverize oat bran into particles with $d_{50}$ equal about 20 micrometer. Although the largest fragmentation was obtained for the highest speed of disc, the satisfying grinding results were also obtained for lower speeds of disc and classifier.

\section{Acknowledgements}

The study was partially financed by the by the National Centre for Research and Development (contract number POIR.01.01.01.-00-0289/17-00) 


\section{References}

AOAC method 995.16 Beta- D- glucan in barley and oats, streamlined enzymatic method (1995).

Bender, A.B.B., Speroni, C.S., Moro, K.I.B., Morisso, F.D.P., dos Santos, D.R., da Silva, L.P., Penna,

N.G. (2020). Effects of micronization on dietary fiber composition, physicochemical properties, phenolic compounds, and antioxidant capacity of grape pomace and its dietary fiber concentrate. LWT-Food Science and Technology, 117, doi:10.1016/j.lwt.2019.108652

Bensalah, F., Harrat, N.I., Affane, F., Chekkal, H., Lamri-Senhadji, M. (2019). Incorporation of whole oat, especially bran, into a high-fat diet, improves cardio-metabolic risk factors in type 2 diabetic rats. Nutrition and Food Science, 49, 600-616.

Chen, T., Zhang, M., Bhandari, B., Yang, Z. (2018). Micronization and nanosizing of particles for an enhanced quality of food: A review. Critical Reviews in Food Science and Nutrition, 58, 993-1001.

Demirbas, A. (2005). $\beta$-Glucan and mineral nutrient contents ofcereals grown in Turkey. Food Chemistry 90,773-777.

Dotsenko, G., Andersson, A. A. M., Andersson, R. (2019). Material disintegration affects enzymatic determination of $\beta$-glucan in barley and oats. Journal of Cereal Science, 88, 138-144.

Dziki, D. (2008). The crushing of wheat kernels and its consequence on the grinding process. Powder Technology, 185, 181-186.

Frohlich, P., Young, G., Bourré, L., Borsuk, Y., Sarkar, A., Sopiwnyk, E.,Pickard, M., Dyck, A., Malcolmson, L. (2019). Effect of premilling treatments on the functional and bread-baking properties of whole yellow pea flour using micronization and pregermination. Cereal Chemistry, 96, 895-907.

Hussain, S., Li, J., Jin, W., Yan, S., Wang, Q. (2018). Effect of micronisation on dietary fibre content and hydration properties of lotus node powder fractions. International. Journal of Food Science and Technology, 53, 590-598.

Liatis, S., Tsapogas, P., Chala, E., Dimosthenopoulos, C., Kyriakopoulos, K., Kapantais, E., Katsilambros, N. (2009). The consumption of bread enriched with betaglucan reduces LDL-cholesterol and improves insulin resistance in patients with type 2 diabetes. Diabetes and Metabolism, 35, 115-120.

Liu, T. Y., Ma, Y., Yu, S. F., Shi, J., Xue, S. (2011). The effect of ball milling treatment on structure and porosity of maize starch granule. Innovative Food Science and Emerging Technologies, 12, 586-593.

Liu, R., Li, J., Wu, T., Li, Q., Meng, Y., Zhang, M. (2015). Effects of ultrafine grinding and cellulase hydrolysis treatment on physicochemical and rheological properties of oat (avena nuda L.) $\beta$-glucans. Journal of Cereal Science, 65, 125-131.

Liu, R., Zhu, T., Li, J., Wu, T., Li, Q., Meng, Y., Cao, Q., Zhang, M. (2016). Physicochemical and antioxidative properties of superfine-ground oat bran polysaccharides. Food Science and Technology Research, 22,101-109.

Protonotariou, S., Stergiou, P., Christaki, M., Mandala, I. G. (2020). Physical properties and sensory evaluation of bread containing micronized whole wheat flour. Food Chemistry, 318, doi:10.1016/j.foodchem.2020.126497.

Romankiewicz, D., Hassoon, W. H., Cacak-Pietrzak, G., Sobczyk, M., Wirkowska-Wojdyła, M., Ceglińska, A., Dziki, D. (2017). The effect of chia seeds (Salvia hispanica L.) addition on quality and nutritional value of wheat bread. Journal of Food Quality, doi:10.1155/2017/7352631.

Salmas, G., DeVries, J. W., Plank, D. (2017). Challenges for dietary fiber: Benefits andcosts of new U.S. regulations. Cereal Foods World, 62, 88-94.

Sibakov, J., Myllymäki, O., Holopainen, U., Kaukovirta-Norja, A., Hietaniemi, V., Pihlava, J.-M., Poutanen, K., Lehtinen, P. (2011). Lipid removal enhances separation of oat grain cell wall material from starch and protein. Journal of Cereal Science, 54, 104-109. 
Stevenson, D.G., Eller, F.J., Jane, J.-L., Inglett, G.E. (2008). Structure and physicochemical properties of defatted and pin-milled oat bran concentrate fractions separated by air-classification. Inter national Journal of Food Science and Technology,43, 995-1003.

Vizuete, A.A., Anta, R.M.O. (2016). Effects of oat beta-glucan intake on blood cholesterol: A review. Dietetica, 20, 127-139.

Wu, Y.V., Doehlert, D.C. (2002). Enrichment of $\beta$-glucan in oat bran by fine grinding and air classification. LWT - Food Science and Technology, 35, 30-33.

Xue, X., Wang, J., Li, S., Zhang, X., Dong, J., Gui, L., Chang, Q. (2020). Effect of micronised oat bran by ultrafine grinding on dietary fibre, texture and rheological characteristic of soft cheese. International Journal of Food Science and Technology, 55, 578-588.

Zhu, F., Du, B., Li, J. (2014). Effect of ultrafine grinding on physicochemical and antioxidant properties of dietary fiber from wine grape pomace. Food Science and Technology International, $20,55-62$.

\title{
ANALIZA SKLADU GRANULOMETRYCZNEGO ZMIKRONIZO- WANEJ WARSTWY OWOCOWO-NASIENNEJ ZIARNA OWSA
}

\begin{abstract}
Streszczenie. Celem pracy była analiza składu granulometrycznego zmikronizowanej warstwy owocowo-nasiennej ziarna owsa. Przed rozdrabnianiem surowiec był poddany procesowi sterylizacji parą przegrzaną o temperaturze $150^{\circ} \mathrm{C}$ przez $3,5 \mathrm{~min}$. Wilgotność surowca po sterylizacji zmniejszyła się z 7,2 do około 3,9\%. Rozdrabnianie przeprowadzono wykorzystując młyn wirnikowy z klasyfikatorem cząstek. Zastosowano cztery prędkości obrotowe wirnika $\left(2600,2970\right.$, 3340, i $\left.3710 \mathrm{obr} \cdot \mathrm{min}^{-1}\right)$. Przy każdej prędkości wirnika stosowano pięć prędkości obrotowych klasyfikatora $(480,965,1450$, 1930, 2410 i $2890 \mathrm{obr} \cdot \mathrm{min}^{-1}$ ). Skład granulometryczny sproszkowanej okrywy ziarna owsa określono metodą dyfrakcji laserowej. Ponadto przeanalizowano skład chemiczny okrywy i przeprowadzone ocenę sensoryczną wyczuwalności większych jej fragmentów na języku, stosując skalę pięciopunktową. Największy stopień rozdrobnienia okrywy uzyskano przy prędkości wirnika wynoszącej $3710 \mathrm{obr} \cdot \mathrm{min}^{-1}$ oraz przy prędkości klasyfikatora równej $1930 \mathrm{obr} \cdot \mathrm{min}^{-1}$. Natomiast w najgorszym stopniu okrywa ulegała mikronizacji przy prędkości wirnika i klasyfikatora równych odpowiednio $3340 \mathrm{obr} \cdot \mathrm{min}^{-1}$ i $480 \mathrm{obr} \cdot \mathrm{min}^{-1}$. Z kolei największą jednorodność wymiarów uzyskiwano przy najniższych prędkościach wirnika i klasyfikatora. Ponadto dla większości zastosowanych warunków mikronizacji nie stwierdzono podczas oceny sensorycznej obecności grubszych cząstek okrywy na języku.
\end{abstract}

Słowa kluczowe: owies, okrywa owocowo-nasienna, mikronizacja, skład granulometryczny cząstek, analiza sensoryczna 